\title{
Radon concentration levels in Fatima Jinnah women university Pakistan
}

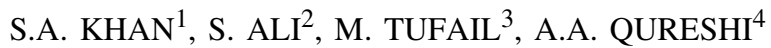

(Manuscript received 25 July 2003, accepted 18 August 2004)

ABSTRACT Public exposure to radioactive gas radon and its progeny present in the air results in the largest contribution to total effective dose received by human beings. It is therefore of great concern to monitor radon concentration in energy conserved air tight buildings. Measurements of radon in the Fatima Jinnah Women University (FJWU) have been carried out for investigation and comparison of radon concentration in the new and old buildings of the campus at Rawalpindi, Pakistan. The study was done because according to the international guidelines concerning environmental problems, it is necessary to evaluate and know the radon levels, especially since most of the natural radiation dose to human beings comes from radon gas and its progeny. Solid State Nuclear Track Detectors (SSNTDs) being efficient, therefore, the measurements were carried out by passive, time integrated method, using CR-39 detector in polythene bags. The detectors were exposed for more than six month in various loctations indoors and outdoors. The detectors were etched using $\mathrm{NaOH}$, the tracks were counted manually, and the track density was converted to radon concentration. Radon concentration varied from 31 to $213 \mathrm{~Bq} \cdot \mathrm{m}^{-3}$ in old building and from 27 to $143 \mathrm{~Bq} \cdot \mathrm{m}^{-3}$ in new buildings, showing slight elevated values in the old buildings. Radon concentration values were found to be less than the values quoted by radiation protection agencies. Radiation dose due to radon varied in the university campus depending on occupancy factor.

Key words: Indoor radon / CR-39 track detector / Lung cancer / Radiation protection

RÉSUMÉ Niveau de concentration en radon dans l'université pour femmes Fatima Jinnah au Pakistan.

L'exposition du public au radon et ses descendants contribue de manière importante à la dose effective reçue par le public. Il est toujours important de surveiller la concentration en radon dans les bâtiments isolés pour la conservation de l'énergie. Des mesures de radon dans l'université pour femmes Fatima Jinnah (FJWU) ont été effectuées et l'on a comparé les concentrations en radon dans les nouveaux et les anciens bâtiments du campus de Rawalpindi au Pakistan. Cette étude a été faite, pour se mettre en adéquation avec les recommandations internationales concernant le radon. Bien que les détecteurs de traces solides (SSNTD) soient efficaces, les mesures ont été faites avec des dosimètres passifs, utilisant le détecteur CR-39 dans des sacs en polyéthylène. Les détecteurs étaient exposés pendant plus de six mois dans différents endroits à l'intérieur et à l'extérieur. Les détecteurs ont été révélés avec de la soude, la lecture des traces effectuée manuellement et leur densité convertie en concentration en radon. Cette concentration varie de 31 à $213 \mathrm{~Bq} . \mathrm{m}^{-3}$

\footnotetext{
Fatima Jinnah Women University, Rawalpindi, Pakistan

Directorate of Safety, PAEC, Islamabad, Pakistan.

PIEAS, P.O. Nilore, Islamabad, Pakistan.

PRD, PINSTECH, P.O. Nilore, Islamabad, Pakistan.
} 


\begin{abstract}
dans les bâtiments anciens et de 27 à 143 Bq.m ${ }^{-3}$ dans les nouveaux bâtiments, montrant ainsi une concentration légèrement plus élevée dans les bâtiments anciens. Les concentrations en radon sont inférieures aux valeurs citées dans les recommandations. Les doses reçues liées au radon dépendent du facteur d'occupation dans l'université.
\end{abstract}

\title{
1. Introduction
}

Radon is a colourless, tasteless, and odourless naturally occurring radioactive gas. It is formed by the natural breakdown of radium (which itself is a decay product of uranium) in soil, rock and water. High levels of radon in the soil and rock are primarily responsible for indoor radon problems. The radon gas percolates up through porous soils under the home or building and enters through gaps and cracks in the foundation or in the insulation and through pipes, sumps, drains, walls and other openings. It enters dwellings most commonly through: cracks in foundations, openings around drains, construction joints, cracks in walls, crawl spaces, and in some cases from well water (EPA, 2003). Water, when in contact with rock containing uranium, absorbs radon gas. The radon is then carried into home and released into the air in household dishwashers, faucets, showers, or washing machines. Building materials are also a source of radon indoors (Sannappa et al., 2003). In some unusual situations, radon may be released from home construction materials such as stone used to build fire places or solar heating storage system.

Radon concentration indoors is affected by several parameters such as radiation sources, microclimate, dwelling engineering, indoor air characteristics and life style of inhabitants. Indoor radon currently is perceived to be the most important problem involving radiation exposure of public. Concentration of radon varies over time indoors. Seasonal variations are harder to protect due to the influence of geography, but for a given location they usually follow a similar pattern from one year to next. In general, the maximum concentration occurs during winter season and minimum concentration in summer season. The outdoor and indoor concentrations in various geological areas reflect the local geology, meaning that higher the radon concentration in the underlying rock and soil, the higher the radon concentration will be indoor. Radon is accumulated in a room due to poor ventilation. Equilibrium is established between accumulation and decay of radon in the closed environment. As radon decays, it forms radioactive byproducts called progeny, decay products or daughters. There are 4 short-lived daughters ${ }^{218} \mathrm{Po},{ }^{214} \mathrm{~Pb},{ }^{214} \mathrm{Bi}$ and ${ }^{214} \mathrm{Po}$ of ${ }^{222} \mathrm{Rn}$. The decay products ${ }^{218} \mathrm{Po}$ and ${ }^{214} \mathrm{Po}$ are $\alpha$ emitters while ${ }^{214} \mathrm{~Pb}$ and ${ }^{214} \mathrm{Bi}$ are $\beta / \gamma$ emitters. Unlike radon the progeny are not gaseous, but rather particulate in nature. They attach themselves to dust particles or other particulates that are suspended in the air (Khan 
et al., 1993). The ratio between progeny and ${ }^{222} \mathrm{Rn}$ gas is called the equilibrium factor.

Among the various radioisotopes of radon, ${ }^{222} \mathrm{Rn}$ is long lived and is a source of radiation dose to the human beings. Onwards from here radon will mean ${ }^{222} \mathrm{Rn}$. The half-life of radon is about 3.82 days whereas the half-lifes of decay products are of the order of minutes and seconds. Therefore when inhaled with air, radon may come out of the lungs without settling and decaying in the lungs but the probability of the short-lived daughter products to stay and decay in the lungs is more. If stayed in the lungs, the radiation may damage the cells. Hence radon is a cause of lung cancer (Alexander, 1995).

Radon problems have been identified in almost every state of the world. In most of the developed countries of the world, the radon problems have been taken seriously. Radon reference and action levels have been set. General public has been made alert of radon through newspapers and electronic media. Free consultant services are provided for measurement and remedial actions against radon. House selling and buying have been linked with radon certification. Surveys of radon emanation are being carried out before laying down the foundation of a new building. Radon prevention and ventilation care techniques are adopted. Old houses with radon concentration above action level are being banned until radon level is reduced by proper mitigation techniques. Training programmes are being offered for measurement and mitigation of radon. New house building techniques are being introduced. A lot of effort is being put into radon publicity campaign. Television advertisements, T-shirts, fridge magnets, cartoon booklets, and videos are being released. Radon awareness weeks have been declared. Radon protection manuals have been prepared. Invitations are being offered for measurement of radon. Separate laboratories have been set for radon analysis. Radon awareness is spreading with the passage of time. Radon measurement has become compulsory by law in some of the countries of the world (EPA, 2003; NRPB, 2003).

In Pakistan, neither publicity campaign nor radon measurement programmes have been started nationwide. Rather small individual efforts for the sake of interest have been done to investigate the radon in some specific area or institution. The present study deals with the measurement of radon concentration in the Fatima Jinnah Women University (FJWU) for the sake of radiation protection of the students, teachers, etc.

\section{Geology of Pakistan}

Geology plays an important role in the contribution of radon built up in any area. It is therefore advisable to describe the geology of Pakistan in brief and that of 


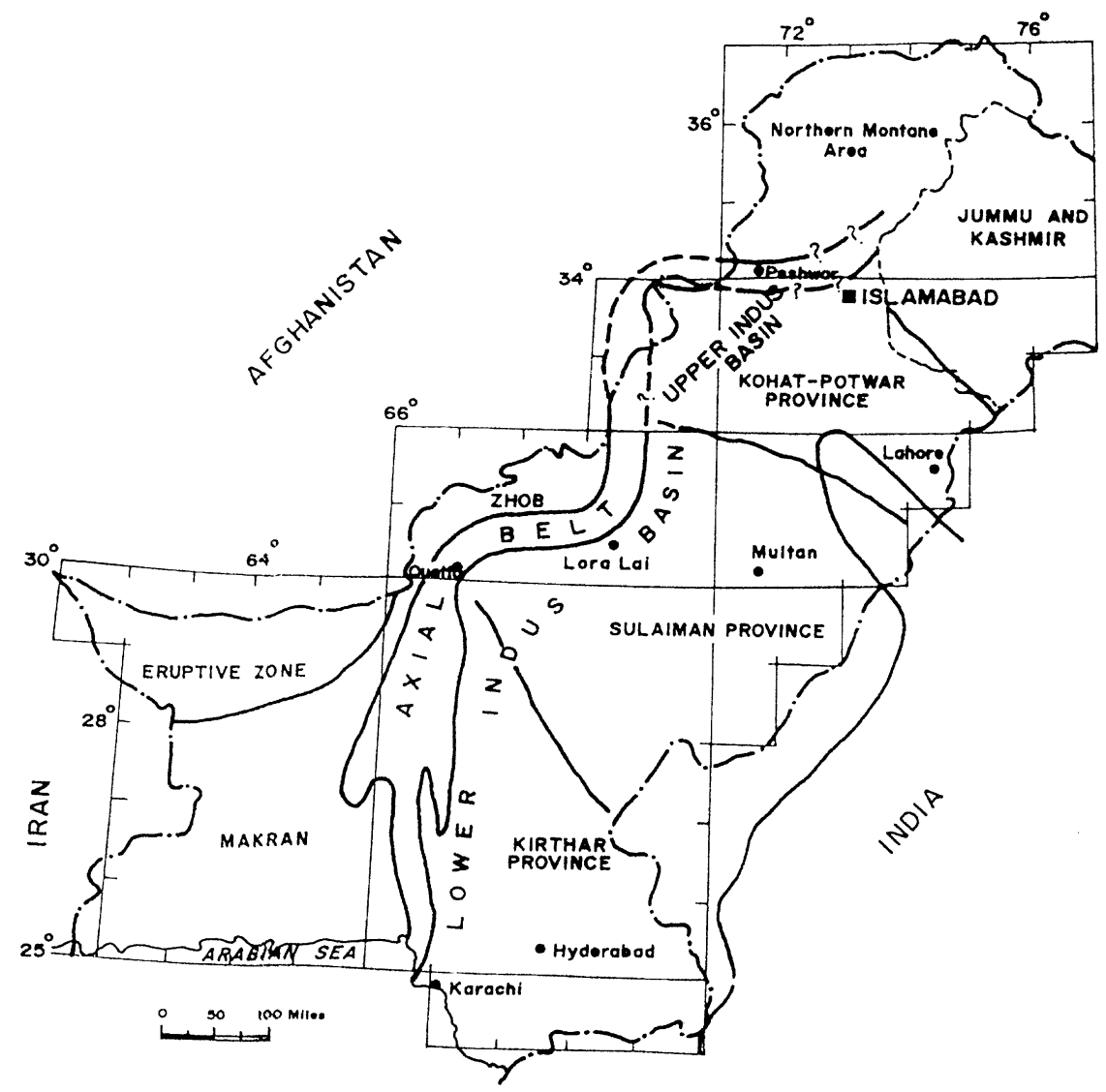

Figure 1 - The map of Pakistan, showing four major geological zones. Northern Montane area consists of the Kurakoram and Himalayan ranges whereas the axial belt consists of mountain ranges-namely White Mountains and Suleman ranges bordering the area between Afghanistan and Pakistan. The Indus basin mainly consists of areas on banks of Indus river flowing in the centre of Pakistan. The alluvial plain occupies the vast area in the eastern part of the country. The FJWU is located in immediate south of Islamabad where recent alluvian overlies the uraniferous Siwalik sequence of about 12 my old.

La carte du Pakistan montrant 4 principales zones géologiques. La zone des montagnes du nord comprend le Kurakoram et les contreforts de l'Himalaya, la ceinture axiale comprend une montagne appelée la Montagne blanche, et les contreforts bordant une zone entre l'Afghanistan et le Pakistan. Le bassin de l'Indus au centre du Pakistan et la plaine alluviale occupe la vaste zone de la partie orientale du pays.

study area in some more detail. Geologically Pakistan can be divided into four major zones (Shah, 1977) as shown in Figure 1 (Baker \& Jakson, 1964) and described briefly as follows. 


\subsection{Northern Montane Area}

The area north of the Islamabad-Peshawar line constitutes the northern montane area. The lower part of the Northern Montane area consists of schists, phyllites, slates, and gneisses of Pre-Cambrian age. These rocks are overlain by a Cambrian sequence of slates, shales, graywacks, and limestones. The upper part of the Northern Montane is composed of limestone of Devonian age. Phyllites, slates, quartizites, limestone/marbles, volcanics, schists, and sandstones of younger age overlie the Devonian rocks again.

\subsection{Axial Belt}

The Axial Belt consists of mountain ranges running north to south from Peshawar to Sui, along the western margin of the country. At Sui these ranges swing towards west towards Quetta and again to south to submerge under the Arabian Sea. This belt is made up of sedimentary lithologies at places intruded by mafic and ultramafic ophiolitic assemblages.

The Axial Belt consists of a complete sequence of rocks from Pre-Cambrian to Carboniferous of slates/phyllites, quartzite beds, limestones dolomites, shales, and siltstones sequence restricted to the upper part. The rocks from Permian to Pleistocene age, consisting of shales, sandstones, limestones, claystones, siltstones and some volcanies, are restricted to southern Axial Belt (Tahir Kheli, 1979).

\subsection{Indus Basin}

The area immediately to the east of axial belt, extending roughly from IslamabadPeshawar line up to the Arabian sea, is called as Indus basin. The Indus basin has been divided into two parts as shown in Figure 1.

\section{Upper Indus Basin}

The Upper Indus Basin has rocks from pre-Cambrian to Pliocene with a gap of Ordovician to Carboniferous period. Here rocks consist of marls, salt, dolomite, and gypsum. This rock sequence is overlain by Permian to Paleocene lithologies consisting of sandstones, shales, silstones, dolomite/limestone, marls, etc. These rocks are overlain by Eocene shales, sandstones, limestones and marls, followed by Miocene-Pliocene sandstones and shales of Murree, Kamlial and Siwalik Formation. This is the area where Fatima Jinnah Women University is located. 


\section{Lower Indus Basin}

The Lower Indus basin consists of a rock sequence of Cretaceous to Miocene age mainly comprising of shales, siltstones, mudstones, limestones, and sandstones. Younger lithologies of Upper Miocene age, shales, sandstones, limestones, and shales of Siwalik Formation are found overlying the older rocks.

\subsection{Alluvial Plain}

The area east of the Indus Basin is termed as Alluvial Plain. Salt range marks the northern boundary of the plain; toward the south it extends up to the Arabian Sea. The plain contains some Pre-Cambrian granitic rocks at Nagar Parker near Karachi. The plain is mainly composed of alluvium, shales, and clays.

\section{Study area}

The area under study is composed of the recent alluvian overlying the Siwalik rocks. The campus of Fatima Jinnah Women University (FJWU) is located in Rawalpindi the twin city of Islamabad which is the capital of Pakistan. The area was chosen for this study; because it consisted of a combination of both new and old construction. Historically it was constructed about a hundred years ago. The FJWU came into existence in December 1998. It is housed in the premises of old presidency building, situated on The Mall, in the heart of Rawalpindi cantonment. Our heritage has been beautifully interlinked with the education of women in this millennium. The main building is Victorian type as reflected in its architectural splendour. It became the presidency of Pakistan in early 1970's. The rooms are steeped in history, many former Presidents; Prime Ministers of Pakistan have walked in its corridors. May be some future Presidents and Prime Ministers are currently walking in these corridors. We have to save the future leaders of the nation from radon. Radon concentration has been measured in different blocks and rooms of this campus using alpha track detectors (FJWU, 2001).

\section{Geology of the study area}

The Fatima Jinnah Women University area is located at longitude $73^{\circ} 15^{\prime} \mathrm{E}$ and latitude $33^{\circ} 16^{\prime} \mathrm{N}$ at a height of about $550 \mathrm{~m}$ above mean sea level. A stream named "Nala Lai" flows about $2 \mathrm{~km}$ north of the study area which discharges its load into the « Sawan River» flowing about $5 \mathrm{~km}$ east. 
The area is covered with $5-10 \mathrm{~m}$ soil cover. The soil cover is composed of Kaolinite, Mica, Quartz, Montmorillonite and some Illite. The oldest rocks exposed in the streams and escarpments belong to Murree Formation (Shah, 1977).

\subsection{Murree Formation}

From top to bottom, four lithological units can be distinguished in Murree Formation:

- light brown hard silt,

- brown hard silty clay,

- dark brown hard clay or claystone,

- dirty grey hard sandstone.

Light brown hard silt is hard but porous and loses strength when wet. Its thickness varies from 1.5-2.0 m. This brown hard silty clay is found almost at every place. The clay content also increases with depth. The thickness of this unit varies from 1.0-4.5 $\mathrm{m}$. The dark brown hard clay bed has chocolate colour and has grey interbedding of clay at places. Occasionally gravels and pebbles are also seen as interbeds. Its thickness varies from 1-2 m. The dirty grey hard sandstone is wellcompacted, massive and hard rock unit. This sandstone consists of quartz, feldspar, mica and zircon.

\subsection{Kamlial Formation}

The Murree Formation is overlain by Kamlial Formations of Miocene/Pliocene age. The Kamlial Formation consists of grey sandstones and brick red shales with intraformational conglomerates. The sandstones are medium to coarse grained and are up to $90 \mathrm{~m}$ thick in this area. At places they are faulted and fractured. These faulted and fractured zones are possibly the water bearing zones indicated by resistivity survey in this area.

\subsection{Siwalik group}

The Kamlial Formation in this area is overlain by rocks of Siwalik Group. Only Lower Siwaliks, represented by Chinji Formation, are exposed $25 \mathrm{~km}$ $\mathrm{N}-\mathrm{E}$ of the area. The Chingi Formation consists of red clay with subordinate ash and grayish sandstone. The sandstones are fine to medium grained and soft. The Chingi formation is the last lithological unit in this area and is overlain by alluvial cover. 
TABLE I

Building architecture and material used in the construction of old and new buildings of the main campus of the university.

Architecture et matériaux utilisés dans les bâtiments anciens et nouveaux du campus principal de l'université.

\begin{tabular}{|c|c|c|}
\hline Parameters & old building & new building \\
\hline Foundation depth & About $1.5 \mathrm{~m}$ & About $1 \mathrm{~m}$ \\
\hline $\begin{array}{l}\text { Foundation width: } \\
\text { at bottom in the ground } \\
\text { at top out of ground }\end{array}$ & $\begin{array}{l}\text { About } 1 \mathrm{~m} \\
\text { About } 0.35 \mathrm{~m}\end{array}$ & $\begin{array}{l}\text { About } 0.75 \mathrm{~m} \\
\text { About } 0.25 \mathrm{~m}\end{array}$ \\
\hline Foundation bed & Crush of clay bricks & $\begin{array}{l}\text { Crush of dolomite covered with } \\
\text { a thick layer of concrete }\end{array}$ \\
\hline Walls material & $\begin{array}{l}\text { Clay bricks and mud, walls } \\
\text { plastered with lime and mud mortar }\end{array}$ & $\begin{array}{l}\text { Concrete iron columns filled } \\
\text { with clay bricks and cement whole } \\
\text { structure plastered with mortar } \\
\text { of cement and sand }\end{array}$ \\
\hline Wall thickness from plinth to ceiling & $0.35 \mathrm{~m}$ & $0.25 \mathrm{~m}$ \\
\hline Ceiling height & $6 \mathrm{~m}$ to $7 \mathrm{~m}$ & $3 \mathrm{~m}$ to $4 \mathrm{~m}$ \\
\hline Floor material & $\begin{array}{l}\text { Made of } 8 \mathrm{~cm} \text { thick clay bricks on } \\
\text { the } 10 \mathrm{~cm} \text { thick crush of clay bricks } \\
\text { over lain by ceramic tiles }\end{array}$ & $\begin{array}{l}\text { Made of } 10 \mathrm{~cm} \text { thick concrete on } \\
\text { the dolomite crush of } 10 \mathrm{~cm} \text { thick } \\
\text { over lain by } 2 \mathrm{~cm} \text { marble }\end{array}$ \\
\hline Ventilation & $\begin{array}{l}\text { Windows at } 1 \mathrm{~m} \text { height from } \\
\text { ground } \\
\text { Ventilators at } 0.3 \mathrm{~m} \text { below ceiling } \\
\text { Corridor between the rooms }\end{array}$ & $\begin{array}{l}\text { Windows at } 1 \mathrm{~m} \text { height from } \\
\text { ground } \\
\text { No ventilators } \\
\text { Verandahs in front of rooms }\end{array}$ \\
\hline
\end{tabular}

\section{Experimental methods}

\subsection{Building material and architect}

The building characteristics such as material, foundation, ceiling height, etc. corresponding to old and new buildings are given in Table I. The 100 years old rooms are with high roofs whereas newly constructed rooms are of medium (class rooms) and low ceiling heights (stores wash rooms) etc.

\subsection{Radon measurements}

The only way to determine if there is a problem in a home or building is by measuring the radon level. Measurement for radon can be done simply and relatively inexpensively. For the measurement of radon concentration in various locations of Fatima Jinnah Women University, passive radon measurement technique with alpha track detectors CR-39 was applied. They were enclosed in a plastic envelope so as to get rid of the radon progeny (Furuta et al., 2002). The envelopes were cataloged and numbered. The number was also engraved on the detector. The envelopes were hung with walls in the rooms at a height of $1 \mathrm{~m}$ from 
TABLE II

Radon concentration in various categories of areas in the Fatima Jinnah University, Rawalpindi, Pakistan.

Concentration en radon dans différentes catégories de zones dans l'université Fatima Jinnah de Rawalpindi au Pakistan.

\begin{tabular}{lccc}
\hline \multirow{2}{*}{ Building } & \multicolumn{3}{c}{ radon concentration $\left(\mathbf{B q} / \mathbf{m}^{\mathbf{3}}\right)$} \\
\cline { 2 - 4 } & minimum & maximum & average \\
\hline Old building & 31 & 213 & 111 \\
New building & 27 & 143 & 78 \\
Closed area & 58 & 213 & 110 \\
Open area & 27 & 45 & 33 \\
Stores / Washrooms & 152 & 165 & 159 \\
Class Rooms (B- \& C-Blocks) & 82 & 213 & 138 \\
Caretaker Block & 92 & 143 & 124 \\
Residential area & 80 & 105 & 92 \\
\hline
\end{tabular}

the ground and at least $10 \mathrm{~cm}$ away from the walls. The detectors were installed in 32 rooms, hallways, verandas and class rooms of academic and residential building of FJWU consisting of new as well as old rooms. These detectors were installed in June 2001 at various places of the university and removed in January 2002. These detectors were exposed in an intermediate, hot and cold season of the year.

After an exposure of 225 days, the CR-39 detectors were removed from the specified positions, and etched in an alkaline solution of $6 \mathrm{M} \mathrm{NaOH}$ at a temperature of $70 \pm 1{ }^{\circ} \mathrm{C}$ for 4 hours (Durrani and Bull, 1987). The detectors were washed in an ultrasonic cleaner. The etched tracks were then counted randomly under an optical microscope at a magnification of $400 \times$ for 30 fields of views of a graduated grid. The area of a field of view was used for conversion of counted tracks to track density (tracks $/ \mathrm{cm}^{2}$ ).

The CR-39 detectors belonging to the same batch as used for radon measurement were exposed to radon of known concentration in a chamber containing radium source. A calibration curve, radon concentration versus track density, was drawn and a polynomial was fitted to the curve. The track density of detectors under study was converted to radon concentration using the calibration curve.

\section{Results and discussion}

The results of this investigation are given in Table II and represented in Figures 2-7. 


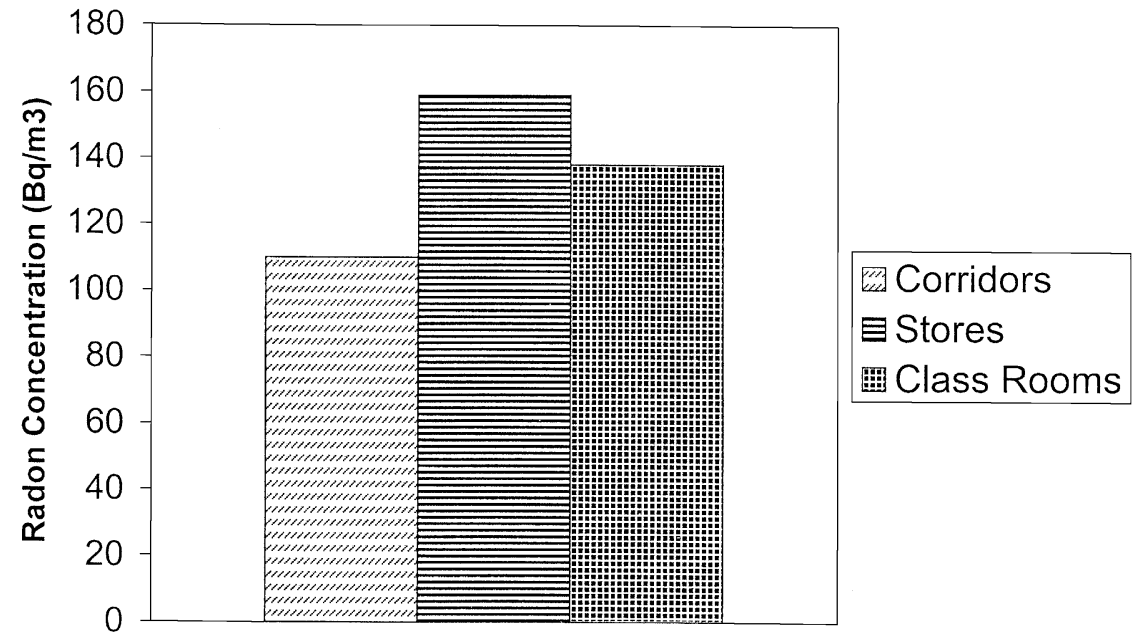

Figure 2 - Radon concentration variations in different categories of rooms in the Fine Arts Department (old building) of FJWU.

Concentration en radon dans différentes catégories de pièces dans le département des beauxarts (bâtiment ancien) de la FJWU.

Figure 2 shows the radon concentration in the Fine Arts Department which exists in the old building of the FJWU campus. The building was constructed more than 100 years ago. The height of ceiling of the rooms in the old building is almost $6.7 \mathrm{~m}$. Radon was measured in the corridors, living rooms (now converted to class rooms) and stores. The concentration of radon in stores was relatively higher than that in the other category of rooms because stores are occasionally opened. Radon concentration was found to be the lowest in the corridors of this building since corridors are well ventilated and open areas. Class rooms were partially kept open, remained closed during night, therefore radon concentration is seen to be in the intermediate between that for stores and corridors.

Figure 3 shows the concentration of radon in the newly constructed building in the campus. This building consists of residential area, caretaker area, and two academic blocks named B-Block and C-Block. Radon concentrations in the residential area, $\mathrm{B}$ and $\mathrm{C}$ blocks were alike within the experimental error. Radon 


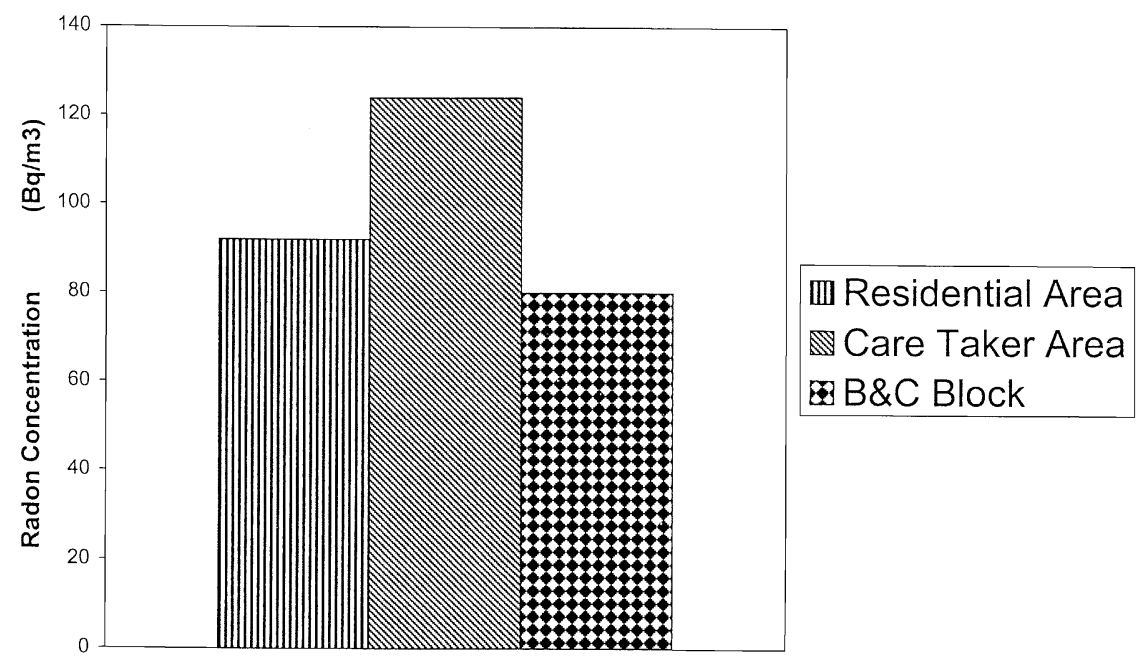

Figure 3-Radon concentration variations in different category of blocks in the newly constructed building of FJWU.

Variations de la concentration en radon dans les différentes parties des bâtiments récemment construits à la FJWU.

concentration is relatively higher in the caretaker area. This area remains closed most of the time and has poor ventilation (in stores and in wash rooms).

Figure 4 compares radon concentration between the old and the newly constructed buildings. The concentration of radon is higher in the old building than in the new building. The height of the rooms in the old building is twice than the height of the rooms in the new building. The rooms of new building are well ventilated and have been constructed using the latest construction skills and proper material composition. The floors are made on thick concrete slabs. There is hardly an opening to the underneath soil. The walls are almost free of cracks. Drainage is not open to the underneath soil. Therefore entrance of radon indoors is controlled in the newly constructed building. The concentration of radon in the old building is relatively high, which may be due to poor ventilation, cracks in the foundation and walls, and because of poor drainage system of the building.

A comparison of radon concentration was also made between the open and covered areas in the university and is shown in Figure 5. The open area includes those places which contain roofs but without doors and windows like verandas; 


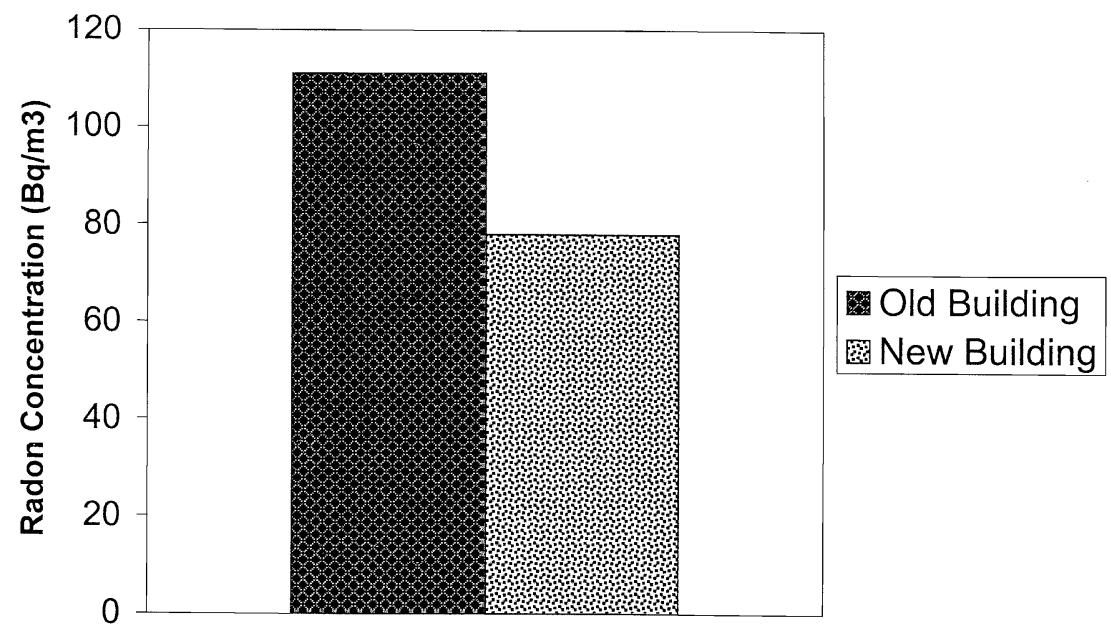

Figure 4 - Comparison of radon concentration in the old and new building in FJWU.

Comparaison des concentrations en radon dans les nouveaux et anciens bâtiments de la FJWU.

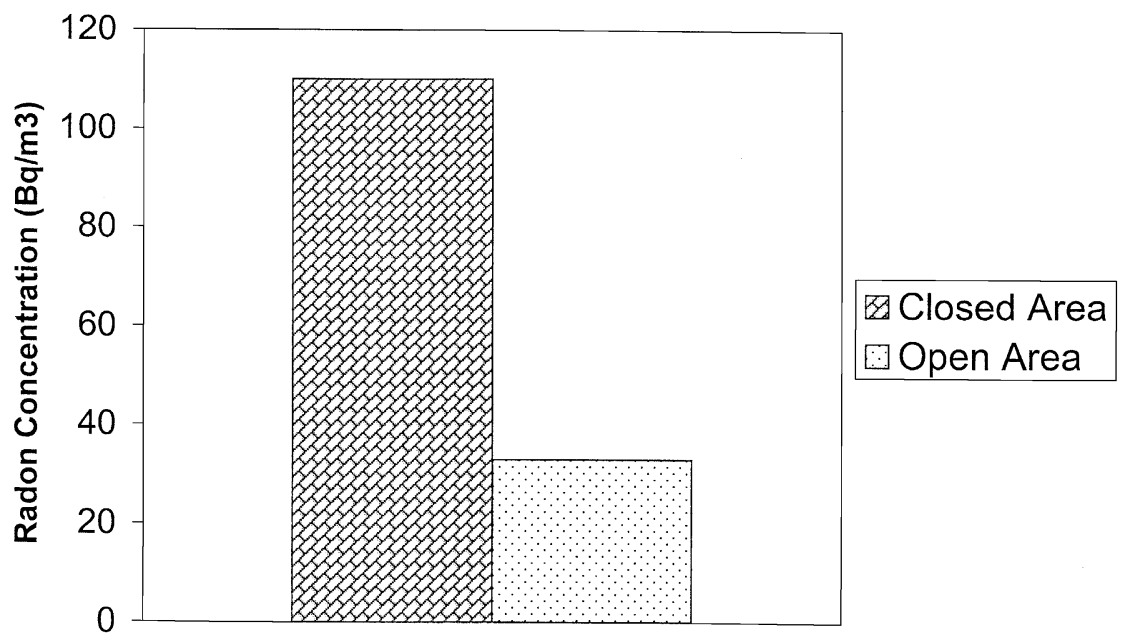

Figure 5 - Comparison of radon concentration in the open and closed areas in FJWU.

Comparaison de la concentration en radon dans les zones fermées et ouvertes de la FJWU. 


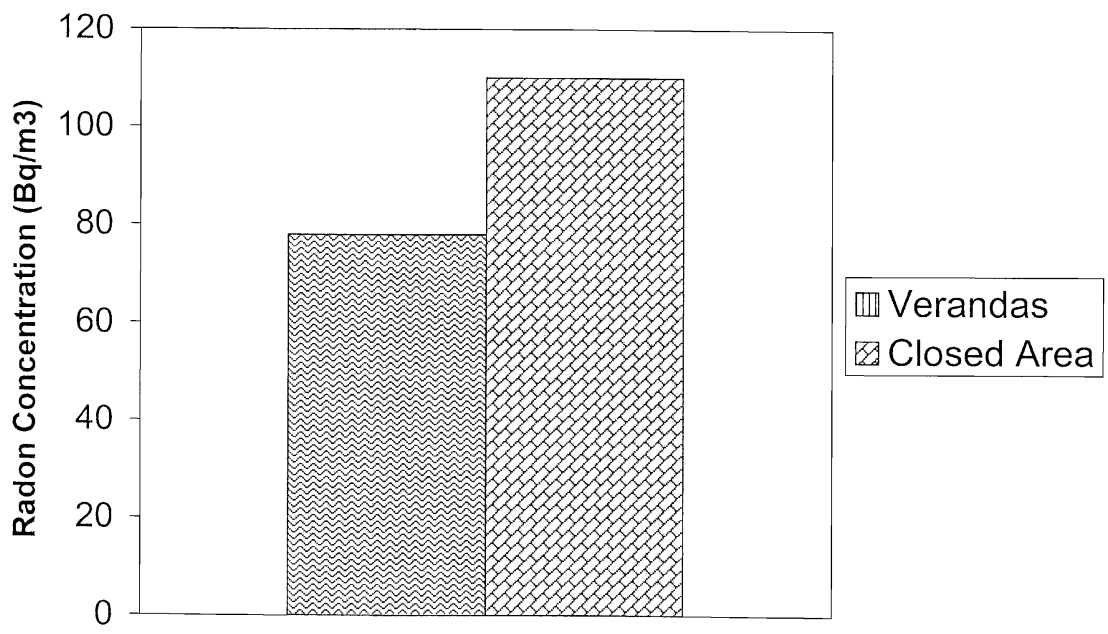

Figure 6 - Comparison of radon concentration in the verandahs and closed areas in FJWU.

Comparaison de la concentration en radon dans les vérandas et parties fermées de la FJWU.

and also the areas without roofs and walls such as yards. The covered area means the areas enclosed within walls and roofs. It is quite obvious from the figure that concentration is higher in the covered area than that in the open area. The reason is obvious that radon accumulates in the places which are kept closed and there is no exchange of fresh air with the air contained in the closed room.

Figure 6 shows a comparison between radon concentration in the verandas and that in the closed areas. Verandas are semi-closed area therefore concentration of radon is relatively less than that in the areas which can be closed with windows and doors.

Figure 7 shows an overall comparison of radon concentration in all types of rooms and open places. The highest radon concentration was found to be in the stores existing in the Fine Arts Department (the old building) and the lowest concentration was found in the $\mathrm{B}-$ and $\mathrm{C}$-blocks (the new building) of the university. Radon concentration in the residential areas is comparable to that in the rooms in the $\mathrm{B}-$ and $\mathrm{C}-$ blocks. All the rooms in the old building have shown comparatively high radon concentration. 


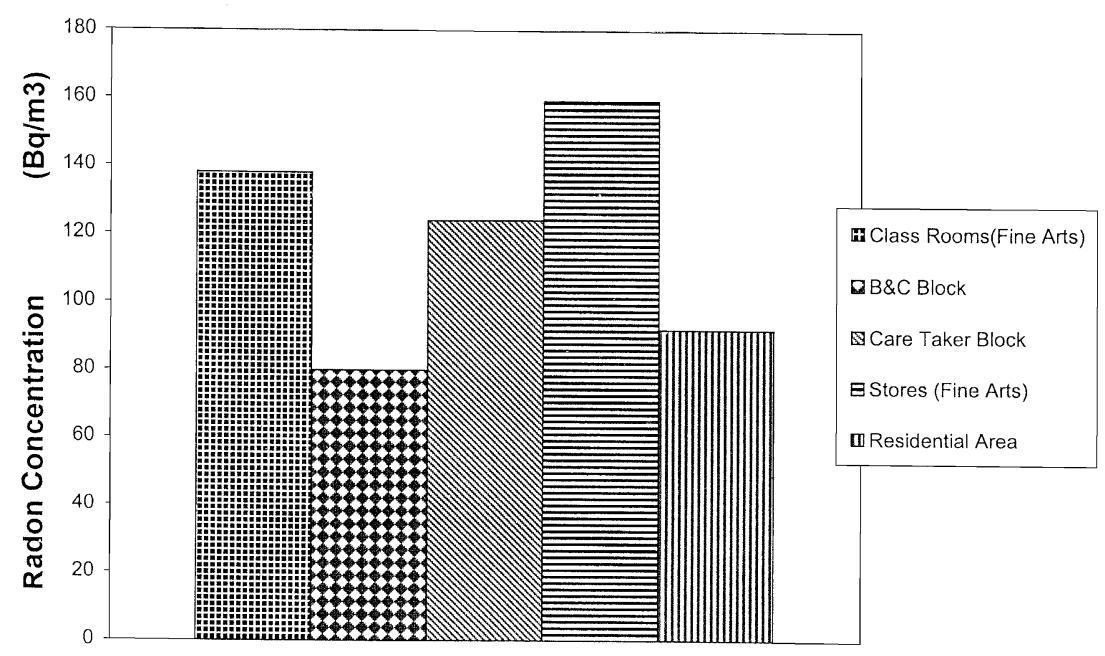

Figure 7 - Comparison of radon concentration in all categories of areas in FJWU.

Comparaison de la concentration en radon dans toutes les catégories de zones à la FJWU.

Radon concentration in places of various categories in the old and new buildings of the university has been compiled in Table II. Range of radon concentration is from 27 to $213 \mathrm{~Bq} \cdot \mathrm{m}^{-3}$. The minimum of the average values is $33 \mathrm{~Bq} \cdot \mathrm{m}^{-3}$ in the open area and the maximum value is $159 \mathrm{~Bq} \cdot \mathrm{m}^{-3}$ in the stores.

The geology of the area indicates that the area under study is not on a compact bed rock. It consists of fractured structure overlain by alluvial deposits of the famous stream "Nala Lai" and the river "Sawan" which derived their sediments from Miocene-Pliocene sediments of Murree, Kamlial and Siwalik Fromations of rapidly rising Himalayas. The underneath material is mainly composed of sand stones. The Siwalik Group of the geological formations is containing uranium content more as compared with the other lithological units.

As seen form Table I, the foundation of the old building is laid on the crush of clay bricks without any further treatment. The foundation walls are made of clay bricks bound with mud. The floor of the building is on a loose material. All these parameters favour the penetration of the soil gas (radon) into the building. The rooms of the old building open in a corridor passing between the rooms. The ventilation is restricted which is a source of radon accumulation in the building. 
The geology and the architect of the old buildings favour the high level of radon concentration in the old building.

For the radiation protection point of view, various countries and the radiation protection agencies of the world have established radon reference levels. The reference levels for some of the countries and radiation protection organizations have been compiled by NRPB (1995). The maximum of the values of radon concentration measured in FJWU is more than the reference levels of Netherlands, Luxembourg, and United States of America, whereas it is less than the levels of most of the countries of the world and the levels of $200-600 \mathrm{~Bq} \cdot \mathrm{m}^{-3}$ set by the IAEA, WHO and ICRP. Ideally the indoor radon concentration should be equal to the outdoor one.

On the basis of action levels of Netherlands, Luxembourg, and United States of America, radon mitigation is required in the old building of FJWU. But based on the action levels of radiation protection agencies, radon is not a big radiation hazard for the students and teachers of this university, since the exposure time is limited for them.

\subsection{Dose estimation}

In order to estimate the annual mean effective dose $\mathrm{H}\left(\mathrm{mSv} \cdot \mathrm{y}^{-1}\right)$ to general public due to radon and its progeny, the conversion factor and the dose calculation model given in UNSCEAR (2000) report was used:

$$
\mathrm{H}=\mathrm{C} \times \mathrm{F} \times \mathrm{O} \times \mathrm{T} \times \mathrm{D}
$$

where, $\mathrm{C}$ stands for radon concentration in Bq. $\mathrm{m}^{-3}, \mathrm{~F}$ for equilibrium equivalent concentration (EEC) factor, $\mathrm{O}$ for occupancy factor, T for time $\left(8760 \mathrm{~h} . \mathrm{y}^{-1}\right)$, and $\mathrm{D}$ for dose conversion factor $\left(9 \times 10^{-6} \mathrm{mSv} \cdot \mathrm{h}^{-1}\right.$ per Bq. $\left.{ }^{-3}\right)$ (UNSCEAR, 2000).

In UNSCEAR report the values of $\mathrm{F}$ and $\mathrm{O}$ are mentioned separately for indoor and outdoor environments and we have used the same values of $F\left(F_{\text {in }}=0.4\right.$ and $\mathrm{F}_{\text {out }}=0.6$ ) whereas the values of $\mathrm{O}$ have been modified. The values of $\mathrm{O}$ in the present case have been selected based on the time spent by the students in the campus. A student spends at the most 12 hours in the university campus. From these 12 hours, the student spends about $80 \%$ time indoors and $20 \%$ outdoors. The values of $\mathrm{O}$ were therefore taken as 0.4 and 0.1 for indoors and outdoors respectively. For the residential area the values of $\mathrm{O}$ were the same as mentioned in UNSCEAR report.

Indoor and outdoor radiation dose due to radon for the people living in the residential area and for the day-scholar of the university has been estimated based on equation (1) and is given in Table III. The world mean dose from environmental 
TABLE III

Radiation dose due to radon in various categories of areas in the Fatima Jinnah University, Rawalpindi, Pakistan.

Dose d'irradiation due au radon dans différentes catégories de zones dans l'université Fatima Jinnah de Rawalpindi au Pakistan.

\begin{tabular}{|c|c|c|c|c|}
\hline \multirow{2}{*}{ Location } & ${ }^{222} \mathrm{Rn}$ conc. $\left(\mathrm{Bq} \mathrm{m}^{-3}\right)$ & EEC & occupancy factor & dose $\left(\mathrm{mSv}_{\mathrm{y}} \mathrm{y}^{-1}\right)$ \\
\hline & $\mathbf{C}$ & $\mathbf{F}$ & $\mathbf{O}$ & $\mathbf{H}$ \\
\hline Old building & 111 & 0.4 & 0.4 & 1.40 \\
\hline New building & 78 & 0.4 & 0.4 & 0.98 \\
\hline Closed area & 110 & 0.4 & 0.4 & 1.39 \\
\hline Open area & 33 & 0.6 & 0.1 & 0.16 \\
\hline Stores / Washrooms & 159 & 0.4 & 0.1 & 0.50 \\
\hline Class Rooms (B- \& C-Blocks) & 138 & 0.4 & 0.4 & 1.74 \\
\hline Caretaker Block & 124 & 0.4 & 0.4 & 1.56 \\
\hline Residential area & 92 & 0.4 & 0.8 & 2.32 \\
\hline
\end{tabular}

${ }^{222} \mathrm{Rn}$ is $1.15 \mathrm{mSv} \cdot \mathrm{y}^{-1}$ (UNSCEAR, 2000). As seen from the table, the dose is mainly depending on the occupancy factor. For the residents of the university, the estimated dose is large as compared with the dose to the students who spend half of the daytime in the university. When compared with the world mean dose from environmental ${ }^{222} \mathrm{Rn}$ of $1.15 \mathrm{mSv}^{-1}$ (UNSCEAR, 2000), some areas of the university show quite larger values than this value.

\section{Conclusions}

The measured values of radon concentration vary in different blocks of FJWU. The old building of the campus showed higher values than those found in the newly constructed blocks. The maximum among the average values of radon concentration was found to be in closed places in the old building. The higher concentration in the old building may be due to inflow of radon from underneath soil through floor, drainage and crawl spaces. The measured radon concentration is less than the reference levels set by various radiation protection agencies. Radon was therefore not a major radiological risk for the inhabitants of this university. The annual dose due to radon in various sections of the university depends on the occupancy factor. The day scholars receive radiation dose less than that recommended by UNSCEAR whereas the residents must improve the ventilation and adopt the mitigation technique to reduce the concentration of radon from the dwellings.

Acknowledgements. The authors are grateful to the FJWU authorities for allowing to undertake this project at the campus of this very old and precious 
heritage. Special thanks to Dr. Najma Najam, Vice-Chancellor, FJWU for encouraging the scientific research related to radiation protection of the students of the university. The assistance of Ms. Tayyaba Nuzhat, Assistant Programme Coordinator is acknowledged for making the drawing of the figures.

\section{REFERENCES}

Alexander F.E. (1995) The search for causes of the leukemia's, Eur. J. Cancer 31, 863-867.

Bakar \& Jakson (1964) Geological map of Pakistan (scale 1:2,000,000) Geological Survey of Pakistan. Durrani S.A., Bull R.K. (1987) Solid State Nuclear Track Detection. Pergamon Press, Oxford.

EPA (2003) Indoor Air: Radon, U.S. Environment Protection Agency (http://www.epa.gov./ iaq/radon/pubs/).

FJWU (2001) Commencement, Fatima Jinnah Women University, Rawalpindi-Pakistan.

Furuta S., Ito K., Ishimori Y. (2002) Measurements of radon around closed uranium mines, $J$. Environm. Rad. 62, 97-114

Khan H.A., Qureshi I.E., Tufail M. (1993) Passive dosimetry of radon and its daughters using solid state nuclear track detectors (SSNTDs), Radiat. Protect. Dosim. 46, 149-170.

NRPB (1995) Radon around the world, Environmental Radon News Letter, Issue 5, Autumn, National Radiological Protection Board (http://www.nrpb.org/publications/newsletters/environmental_ radon/archive/1995/ern5.pdf).

NRPB (2003) Radon, National Radiological Protection Board, UK (http://www.nrpb.org/ radon/index.htm).

Sannappa J., Chandrashekara M.S., Sathish L.A., Paramesh L., Venkataramaiah P. (2003) Study of background radiation dose in Mysore city, Karnataka State, India, Radiat. Meas. 37, 55-65

Shah S.M.I. (1977) Strategraphy of Pakistan, Memoirs of Geological Survey of Pakistan.

Tahir Kheli R.A.K. (1979) Geotectonic evolution of Kohistan, Geological Bulletin, University of Peshawar (special issue).

UNSCEAR (2000) Sources and effects of ionizing radiation, United Nations Scientific Committee on the Effects of Atomic Radiation, Report to General Assembly, New York (http://www.unscear.org/reports/2000_1.html). 